\title{
Purification of pituitary autoantigen by column liquid chromatography and chromatofocusing
}

\author{
PAWE€ GUT, JAKUB FISCHBACH, KATARZYNA ZIEMNICKA, MACIEJ BĄCZYK, \\ DARIA BASZKO-BEASZYK, ELŻBIETA WROTKOWSKA, MAREK RUCHAŁA
}

Department of Endocrinology, Metabolism and Internal Diseases, Poznan University of Medical Sciences, Poland

\begin{abstract}
Introduction: Pituitary autoantibodies can be determined both in patients with pituitary disease as well as patients with autoimmune endocrine diseases. The purpose of the study was to isolate and purify pituitary autoantigen using sera of patients and the microsomal fraction of the pituitary.

Material and methods: To isolate a pituitary autoantigen, patient sera were used, which showed a strong immune response to pituitary antigens. Pituitary microsomal fractions were prepared from pituitary tissue homogenates. In the study, sera of patients with pituitary disease, Addison and Graves' disease were used. The initial stages were carried out by affinity chromatography on $\mathrm{CN}-\mathrm{Br}$ sepharose column whereas purification was continued by column liquid chromatography on AcA54 Ultrogel. Chromatofocusing was performed by Polybuffer exchanger PBE 94.

Results: ${ }^{125}$ I-labeled pituitary antigens after isolation appeared in column chromatography in three peaks. The first peak contained 50-70 kDa proteins, the second peak - 17 to $22 \mathrm{kDa}$ proteins and the third peak contains ${ }^{125}$-iodides. Three fractions obtained from filtration on Ultrogel were separated in a polyacrylamide gel. In the first peak two bands 67 and $55 \mathrm{kDa}$ appeared. The second peak contained low molecular weight substances, and the third peak contained ${ }^{125} I$. The first peak from Ultrogel was isolated by chromatofocusing - the first peak with pH 5.9 and the second one with pH 4.9.

Conclusions: Isolation and purification of pituitary autoantigen with the use of column liquid chromatography and chromatofocusing resulted in obtainment of two antigenic proteins of specific gravity of 67 and $55 \mathrm{kDa}$.
\end{abstract}

Key words: pituitary autoantigen, purification, column liquid chromatography, chromatofocusing.

(Centr Eur J Immunol 2014; 39 (1): 46-50)

\section{Introduction}

The presence of pituitary antibodies was noted for the first time in 1962, when Goudie and Pinkerton [1] observed the disappearance of the pituitary in a young woman with Hashimoto disease. However, the systematic study of this problem began in the 1970s. In 1974-75, Bottazzo $[2,3]$ proved by immunofluorescence that in patients with Addison's disease various organ antibodies can often be determined. He also claimed $[4,5]$ that the antibodies are directed against components of cell membranes and the microsomal fraction of cells. In 1981, Mirakian [6] published data on the presence of prevalence of anti-insular and anti-pituitary antibodies in patients with type I diabetes. In 1988, Komatsu [7] observed the presence of pituitary antibodies in $70 \%$ of patients with an empty sella syndrome. Crock [8] studied the occurrence of pituitary antibodies in various autoimmunological endocrinopathies with the use of autoimmune pituitary cytosolic fraction isolated from the pituitary based on immunoblotting. These studies revealed the presence of antibodies against the protein of the human pituitary with a weight of 40 and $49 \mathrm{kDa}$ in $70 \%$ of patients with lymphocytic hypophysitis and $42 \%$ of patients with Addison's disease and $15 \%$ of patients with Graves' disease. Identification and characterization of autoantigens specific to particular endocrine glands is an integral part in understanding the pathogenesis of autoimmune diseases. In most cases, organ-specific autoantigens are molecules with a well-explored protein activity and function as enzymes, receptors or other cellular structures [9]. Shelly reported that hyperprolactinemia has a signif-

Correspondence: Paweł Gut, PhD, Department of Endocrinology, Metabolism and Internal Diseases, Poznan University of Medical Sciences, Przybyszewskiego 49, 60-355 Poznań, Poland, tel. +48 6186913 30, fax +48 61869 16 82, e-mail: gutpj@ poczta.onet.pl 
icant influence on the induction of immunomodulating autoimmune processes and disclosure of autoimmune diseases [10]. Pituitary and hypothalamic autoantibodies especially directed against vasopressin-secreting cells can cause lymphocytic hypophysitis and hypothalamitis giving signs of hypopituitarism and diabetes insipidus [11]. The aim of this study was to attempt of isolation of pituitary autoantigen with the use of both sera of patients with high titres of pituitary autoantibodies and the microsomal fraction of human pituitaries. The results of pituitary antigen isolation by affinity chromatography were presented in our previous work [12]. The present results are a continuation of attempts of pituitary antigen purification by column liquid chromatography and chromatofocusing.

\section{Material and methods}

For the research we chose the sera of patients with pituitary disease (acromegaly, prolactinoma) and both Addison's disease and Graves' disease showing strong immune response to pituitary microsomal fraction 55, 60 and 67 $\mathrm{kDa}$ proteins, as the most prevalent in our study.

To obtain microsomal fraction of human pituitaries needed to isolate a pituitary autoantigen, ultracentrifugation and solubilization in $1 \%$ sodium deoxycholate were used. Human pituitaries obtained from autopsies, stored until isolation of microsomal fraction at $-70^{\circ} \mathrm{C}$, were used in the study. Immunoglobulins were isolated from the sera of patients with high titers of pituitary autoantibodies with use of column Protein A-sepharose CL-4B. The column was prepared from $1 \mathrm{~g}$ sepharose. Next 1-1.5 ml of patient serum was applied to the prepared column and incubated for 2 hours at room temperature. Immunoglobulins associated with Protein A-Sepharose were desorbed by $0.56 \%$ acetic acid. The protein concentration in the eluate was determined spectrophotometrically at a wavelength of $280 \mathrm{~nm}$. To prepare the immunosorbent, patients' immunoglobulins were covalently coupled to $\mathrm{CNBr}$-activated sepharose. Pituitary microsomal autoantigen isolation was carried out on the column of immunosorbent applying solubilized microsomal protein of the pituitary in amounts of 30 to $50 \mathrm{mg}$ in $4 \mathrm{ml}$ of $0.05 \mathrm{~mol} / \mathrm{l} \mathrm{pH} 7.4$ phosphate buffer with $0.1 \%$ sodium deoxycholate. The column was closed and the sorbent with microsomal proteins was mixed on a shaker for 3 hours at room temperature. Desorption of antigen proteins bound with antibodies was done with the use of $0.2 \mathrm{~mol} / \mathrm{l} \mathrm{pH} 2.8$ glycine- $\mathrm{HCl}$ buffer, guanidine $1 \mathrm{~mol} / \mathrm{l}$ and guanidine $3 \mathrm{~mol} / \mathrm{l}$, collecting fractions of $1 \mathrm{ml}$. Protein content was assessed by spectrophotometry (OD $280 \mathrm{~nm}$ ). ${ }^{125}$ I radiolabeled antigenic pituitary proteins isolated by affinity chromatography were purified by liquid chromatography on a column of AcA54 Ultrogel $1 \times 50$ $\mathrm{cm}$ to separate the antigens of different molecular weight. The columns were saturated with $1 \mathrm{ml}$ of $5 \%$ albumin to reduce adsorption of filtrated proteins and calibrated with
${ }^{125}$ I-labeled proteins: bovine serum albumin with mass of $67 \mathrm{kDa}, 44 \mathrm{kDa}$ staphylococcal protein A, alpha subunit $(17.5 \mathrm{kDa})$ and sodium iodide ${ }^{125} \mathrm{I}-\mathrm{Na}$ (139 Da). After application of ${ }^{125}$ I-labeled pituitary antigens, the column was eluted with a phosphate buffer with $0.1 \%$ sodium deoxycholate, collecting $1 \mathrm{ml}$ of fractions and determining the radioactivity of each fraction.

Chromatofocusing columns were performed by polybuffer exchanger (Polybuffer exchanger - PBE 94). This enabled the separation of proteins according to their isoelectric point. To $5 \mathrm{ml}$ of the PBE gel $50 \mathrm{ml}$ of starting buffer $0.025 \mathrm{~mol} / 1$ Tris-CH3COOH $\mathrm{pH} 8.3$ was added. The gel was then transferred to a glass column of $23 \mathrm{~cm}$ and a diameter of $5 \mathrm{~mm}$. The column was washed with $50 \mathrm{ml}$ of starting buffer. Then, on the gel was applied 125I-labeled pituitary proteins and the column was eluted by elution buffer at $\mathrm{pH}$ 4.0. Elution buffer was composed from $3 \mathrm{ml}$ of Polybuffer 96, $7 \mathrm{ml}$ of Polybuffer 74 and $90 \mathrm{ml}$ of distilled water. The PBE 94 column during elution gradually changing the $\mathrm{pH}$ of their environment from 8.3 to 4.0 for attaining appropriate isoelectric point of the separated protein. Fifty fractions were collected with a volume of $1 \mathrm{ml}$, and then in each fraction was measured $\mathrm{pH}$ and radioactivity. Fractions containing the highest activity of pituitary purified antigens was assessed by polyacrylamide gel electrophoresis.

\section{Results}

AcA54 Ultrogel columns with separation ability of proteins with masses between 5000 and 70000 Da. were applied to column liquid chromatography. Calibrations of the Ultrogel AcA54 column with the use of ${ }^{125} \mathrm{I}-\mathrm{la}$ beled proteins with known specific gravity were carried out several times before the research. The study showed that ${ }^{125}$ I-labeled bovine serum albumin $(67 \mathrm{kDa})$ is eluted from the column in fractions 7, 8 and 9, the ${ }^{125}$ I-labeled protein $\mathrm{A}(41 \mathrm{kDa})$ in fractions 8 and 9 , the ${ }^{125}$ I-labeled alpha subunit (17.5 kDa) in fractions 19-20, and iodides, ${ }^{125} \mathrm{I}$ - (125 Da) in fractions 30-35. Superimposed on the column ${ }^{125}$ I-labeled pituitary antigens, which were previously isolated by affinity chromatography, were eluted from the column in three distinct peaks. The first peak covered fractions 8-10, and thus included 50-70 kDa proteins. The second peak appeared in fractions 16-18 and correlated with 17 to $22 \mathrm{kDa}$ proteins, whereas the third peak (fractions 3035 ) contained 125 - iodides. In order to assess the various peak fractions, precipitation of immune complexes with the use of $10 \%$ trichloroacetic acid, adding sera with high titers of pituitary autoantibodies to labeled fractions $(20 \mu \mathrm{l}$ serum, $20 \mu \mathrm{l}$ of the ${ }^{125} \mathrm{I}$ fraction - the pituitary antigen from column chromatography, and $1 \mathrm{ml} 10 \%$ TCA) was done. Precipitation was $76 \%$ for the first peak, $37 \%$ of the second peak and $9 \%$ iodide peak, indicating that the antigenic proteins were mainly found in the top of the first. Three peaks 


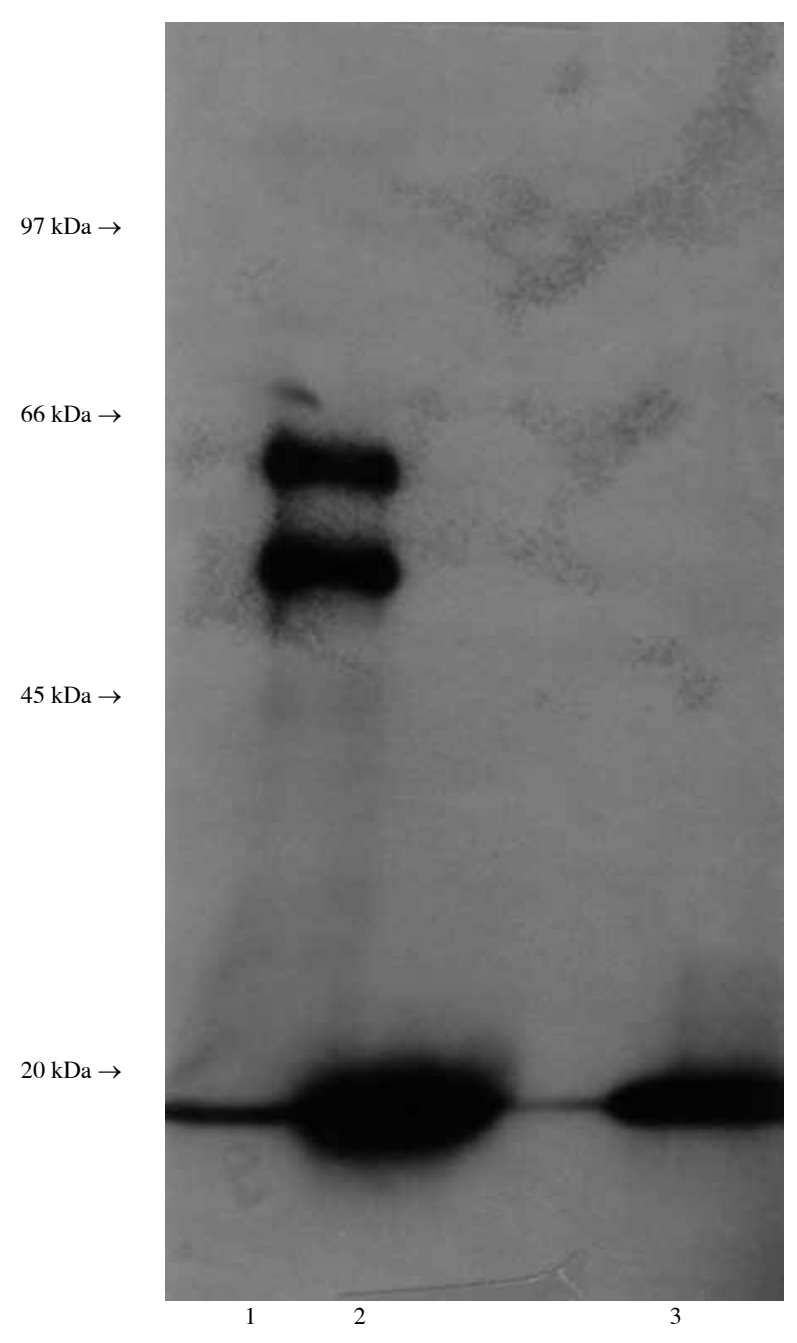

Fig. 1. ${ }^{125}$ I-labeled pituitary antigens after purification on column of AcA54 Ultrogel separated on a polyacrylamide gel electrophoresis (SDS/PAGE/Western-blotting) 1. First peak (fractions 8-10) proteins with molecular weight of 67 and $55 \mathrm{kDa}$

2. Second peak (fractions 16-18) proteins with molecular weight below $20 \mathrm{kDa}$

3. Third peak (fractions 30-35) 125 - iodides

obtained from liquid chromatography were also examined by solid phase binding reaction of ${ }^{125}$ I labeled - pituitary antigens with isolated antibodies coated on polyethylene tubes by RIA. As with the precipitation method, only the first peak showed a bond with the antibody. Three radioactive fractions obtained from the filtration on AcA54 Ultrogel were also subjected to separation electrophoretically on a polyacrylamide gel (SDS-PAGE) followed by autoradiography. In the first peak, study revealed two 67 $\mathrm{kDa}$ and $55 \mathrm{kDa}$ bands. The second peak contained the low molecular weight substances of less than $20 \mathrm{kDa}$, while the third peak except 125 - iodide did not contain

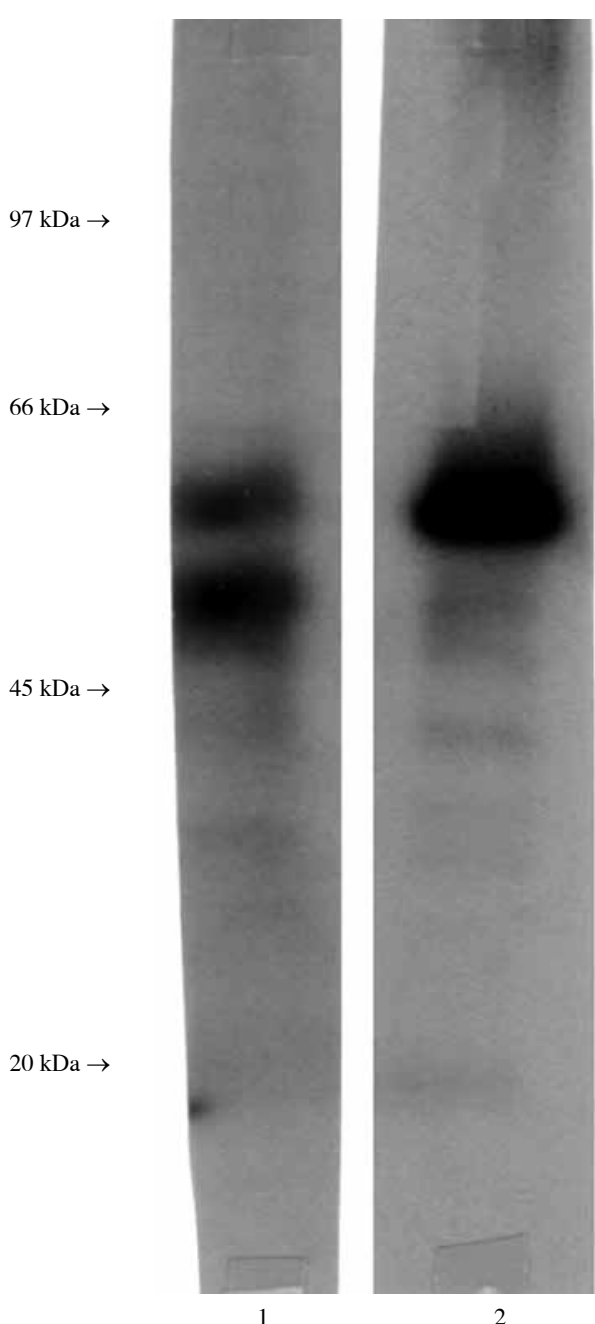

Fig. 2. ${ }^{125}$ I-labeled pituitary antigens after purification on chromatofocusing and separated on a polyacrylamide gel electrophoresis (SDS-PAGE/Western-blotting) 1. First peak - two bands of 67 and $55 \mathrm{kDa}$ weight 2. Second peak - one clear band with a mass $67 \mathrm{kDa}$ and a trace amount of low molecular weight proteins

proteins (Fig. 1). Chromatofocusing was performed on the column prepared by polybuffer exchanger (Polybuffer exchanger PBE 94). Proteins separated by chromatofocusing on reaching a $\mathrm{pH}$ equivalent to isoelectric point $(\mathrm{pI})$ were gradually eluted from the column. This created the possibility of separation of the two protein fractions gravities 67 and $55 \mathrm{kDa}$, obtained after isolation by affinity chromatography and column liquid chromatography. Applied to the chromatofocusing column ${ }^{125}$ I-labeled antigens appeared only in fractions with $\mathrm{pH}$ below 7.6 as two distinct peaks, the first more extensive, diffuse with a maximum at $\mathrm{pH}$ 5.9 and a second peak, sharp with a maximum at $\mathrm{pH} 4.9$. 
Two radioactive peaks at $\mathrm{pH} 5.9$ and 4.9 was separated on a polyacrylamide gel (SDS-PAGE) and autoradiography was performed. The first radioactive peak at $\mathrm{pH} 5.9$ gave two distinct bands of mass 67 and $55 \mathrm{kDa}$, identical to the first peak eluted from the AcA54 column. However, the fraction eluted from the column at $\mathrm{pH} 4.9$ presented one distinct band at $67 \mathrm{kDa}$ mass (Fig. 2).

\section{Discussion}

Attempts to isolate autoantigens responsible for autoimmune processes open up a numerous possibilities for studies and development of methods for the determination of autoantibodies and their characteristics [13]. According to the previous studies, knowing the reaction of protein antigens with specific autoantibodies, isolation and purification of autoantigens from native human tissues are applied by using methods such as affinity chromatography, column liquid chromatography, chromatofocusing or high pressure liquid chromatography [14]. Komatsu's research [7] suggested connection between pituitary atrophy or empty sella syndrome with the presence of antibodies against the cells of the pituitary [15] in the immunocytochemical studies reported the presence of antibodies reacting mainly with pituitary cells producing growth hormone and prolactin. Vercammen [16] described in the sera of patients with freshly diagnosed diabetes mellitus type I the presence of antibodies reacting with antigens of the pituitary. Baekkeskov [17] in their detailed study demonstrates that these antibodies react in most cases with the antigenic proteins of human pituitary with weight 22 and $64 \mathrm{kDa}$. Bensing and Kasperlik-Załuska [18, 19] described the presence of antibodies in an isolated pituitary ACTH deficiency. In the study an antigenic proteins isolated from the cytosolic fraction were used and in $19 \%$ of cases antibodies against the antigens 36 and $49 \mathrm{kDa}$ were determined. In subsequent studies, O'Dwyer [20] identified the $49 \mathrm{kDa}$ pituitary antigen as neurospecifi $\alpha$-enolase. According to the previous studies, it is considered that the incidence of pituitary antibodies directed against specific gravity $67 \mathrm{kDa}$ pituitary autoantigens in conjunction with insulin dependent diabetes may suggest that the pituitary autoantigen, as in type I diabetes, could be the glutamic acid decarboxylase (GAD) [21].

Moya Chimenti [22] reported that pituitary antibodies are present in $43 \%$ of patients with isolated ACTH deficiency. On the other hand, Yamamoto [23] describes the presence of antibodies against the pituitary transcription factor PIT-1 in patients with growth hormone prolactin and TSH insufficiency. It turns out that growth hormone and proopiomelanocortin are pituitary autoantigens in patients with both lymphocytic hypophisitis and acromegaly [24, 25]. Smith et al. [26] labeled anti-pituitary antibodies against PGSF1a and PGSF2 (pituitary gland specific factor 1a, 2 in approximately $15 \%$ of patients with lymphocytic hypophisitis. As the data cited above show, there are many reports describing the exponents of autoimmune processes related to pituitary antigens, but the essence of these changes, their meaning and nature of autoantigens still requires further explanation. In our study, attempts to isolate the pituitary autoantigen with the use of column liquid chromatography allowed us to obtain two protein antigens fractions with different molecular weights 67 and $55 \mathrm{kDa}$. This lower line $55 \mathrm{kDa}$ is very close to $49 \mathrm{kDa}$, so it could be alpha enolase. Unfortunately, both the quantity and purity of autoantigens isolated in our study did not allow on their further and more detailed characterization. Therefore, further studies are still needed to obtain the purified form of pituitary autoantigen in such quantities that research might be performed not only qualitative but also quantitative, and then it will be possible to reproduce the disease in an animal model.

\section{Authors declare no conflict of interest.}

\section{References}

1. Goudie RB, Pinkerton PH (1962): Anterior hypophysitis and Hashimoto disease in a young woman. J Pathol Bacteriol 83: 584-585.

2. Bottazzo GF, Pouplard A, Florin-Christensen A, Doniach D (1975): Autoantibodies to prolactin secreting cells of human pituitary. Lancet 2: 97-101.

3. Bottazzo GF, McIntosh C, Stanford W, Preece M (1980): Growth hormone cell antibodies and partial growth hormone deficiency in a girl with Turner's syndrome. Clin Endocrinol 12: 1-9.

4. Sotsiou F, Bottazzo GF, Doniach D (1980): Immunofluorescence studies on autoantibodies to steroid-producing cells, and to germline cells in endocrine disease and infertility. Clin Exp Immunol 39: 97-111.

5. Doniach D, Bottazzo GF (1977): Pancreatic autoimmunity and diabetes mellitus. Neth J Med 20: 245-247.

6. Mirakian R, Bottazzo GF, Doniach D (1980): Autoantibodies to duodenal gastric-inhibitory-peptide (GIP) cells and to secretin (S) cells in patients with celiac disease, tropical sprue, and maturity-onset diabetes. Clin Exp Immunol 41: 33-42.

7. Komatsu M, Kondo T, Yamauchi K (1988): Antipituitary antibodies in patients with the primary empty sella syndrome. J Clin Endocrinol Metab 67: 633-638.

8. Crock PA (1998): Cytosolic autoantigens in lymphocytic hypophysitis. J Clin Endocrinol Metab 83: 609-618.

9. Riley WJ (1995): Enzymes as antigens in autoimmune endocrinopathies. Clin Chem 41: 337-339.

10. Shelly S, Boaz M, Orbach H (2012): Prolactin and autoimmunity. Autoimmun Rev 11: A465-467.

11. De Bellis A, Sinisi AA, Pane E, et al. (2012): Involvement of hypothalamus autoimmunity in patients with autoimmune hypopituitarism: role of antibodies to hypothalamic cells. J Clin Endocrinol Metab 97: 3684-3690.

12. Gut P, Kosowicz J, Ziemnicka K, et al. (2009): Isolation of pituitary autoantigen by affinity chromatography. Endokrynol Pol 60: 455-460.

13. Czarnocka B, Ruf J, Ferrand M, et al. (1985): Purification of the human thyroid peroxidase and its identification as the mi- 
crosomal antigen involved in autoimmune thyroid diseases. FEBS Lett 190: 147-152.

14. Furmaniak J, Kominami S, Asawa T, et al. (1994): Autoimmune Addison's disease - evidence for a role of steroid 21 hydroxylase autoantibodies in adrenal insufficiency. J Clin Endocrinol Metab 79: 1517-1521.

15. Hansen BL, Hegedüs L, Hansen GN, et al. (1989): Pituitary cell autoantibody diversity in sera from patients with untreated Graves disease. Autoimmunity 5: 49-57.

16. Vercammen M, Gorus F, Foriers A, et al. (1989): Cell surface antibodies in type 1 (insulin-dependent) diabetic patients. Presence of immunoglobulin $\mathrm{M}$ which bind to rat pituitary cells. Diabetologia 32: 611-617.

17. Baekkeskov S, Aanstoot HJ, Christgau S (1990): Identification of the $64 \mathrm{kDa}$ autoantigen in insulin dependent diabetes as the GABA synthesizing enzyme glutamic acid decarboxylase. Nature 347: 151-156.

18. Bensing S, Kasperlik-Zaluska AA, Czarnocka B, et al. (2005): Autoantibodies against pituitary proteins in patients with adrenocorticotropin deficiency. Eur J Clin Invest 35: 126-132.

19. Kasperlik-Załuska AA, Czarnocka B, Czech W (2003): Autoimmunity as the most frequent cause of idiopathic secondary adrenal insufficiency: report of 111 cases. Autoimmunity 36: 155-159.

20. O'Dwyer DT, Smith AI, Matthew ML (2002): Identification of the 49-kDa autoantigen associated with lymphocytic lymphophysitis as $\alpha$-enolase. J Clin Endocrinol Metab 87: 752-757.

21. Christie MR, Brown TJ, Cassidy D (1992): Binding of antibodies in sera from type1 (insulin dependent) diabetic patients to glutamate decarboxylase from rat tissues. Evidence for antigenic and non antigenic forms of the enzyme. Diabetologia 35: 380-384.

22. Moya Chimenti E, Alvarez Doforno R, Villaroel Bajo A, et al. (2010): Antipituitary antibodies in patients with suspected autoimmune hypophysitis. Endocrinol Nutr 57: 160-164.

23. Yamamoto M, Iguchi G, Takeno R, et al. (2011): Adult combined GH, prolactin, and TSH deficiency associated with circulating PIT-1 antibody in humans. J Clin Invest 121: 113119.

24. Landek-Salgado MA, Leporati P, Lupi I, et al. (2012): Growth hormone and proopiomelanocortin are targeted by autoantibodies in a patent with biopsy-proven IgG4 related hypophysitis. Pituitary 15: 412-419.

25. Guaraldi F, Caturegli P, Salvatori R (2012): Prevalence of antipituitary antibodies in acromegaly. Pituitary 15: 490-494.

26. Smith CJ, Bensing S, Burns C, et al. (2012): Identification of TPIT and other novel autoantigens in lymphocytic hypophysitis: immunoscreening of a pituitary cDNA library and development of immunoprecipitation assays. Eur J Endocrinol 166: 391-398. 